\title{
Power and Limitations of Media Clearance Practices and Advertising Self-Regulation
}

\author{
Herbert J. Rotfeld
}

\begin{abstract}
Self-regulation programs deter many advertising practices, but there are inherent limitations to its power in the United States. U.S. media vehicle managers' advertising acceptance policies may influence advertising content, but their decisions often are focused on priorities other than consumer protection. This article describes the power limitations of U.S. selfregulation and media advertising acceptance policies, showing how self-regulation alone is unable to fulfill the public policy goal of discouraging false advertising during government deregulation.
\end{abstract}

A dvertising self-regulation programs are often presented as evidence of the decreasing need for government involvement. Repeated descriptions of business-run programs imply that self-regulation alone, including the "clearance process" by which media vehicles decide what advertising would be published or broadcast, could adequately limit deceptive advertising. [e.g., Marketing News 1985; Boddewyn 1989; Colford 1987a; Hamm 1988; LaBarbera 1980; Oliver 1988; Sewell and Jennerjahn 1982; Zanot 1985].

Contrary to popular belief, U.S. self-regulation of advertising deception is unable to fill the void that may be left by government during times of deregulation. With a longstanding public policy goal of discouraging deceptive advertising practices, self-regulation alone cannot serve that purpose. This article attempts to clarify self-regulation's power in the United States, pointing out its limitations in relation to government consumer protection programs. The literature review and analysis reveals that the power of selfregulation by trade association codes is in direct proportion to the threat of government regulation, while media standards for acceptable advertising have different goals than those of government consumer protection programs.

\section{Advertising, Consumer Protection \& Market Information}

Some critics of business practices might desire "protection" from offensive or obscene advertising, but United States laws rarely intrude on issues of advertising taste. ${ }^{1}$ The federal consumer protection concerns for advertising could simply be phrased in terms of whether consumers are provided with true information, so that advertising messages do not leave consumers with a false impression.

Although advertising is a major source of market information for U.S. consumers, there exist several limitations to

Herbert J. Rotfeld is an Associate Professor of Marketing and Adjunct Associate Professor of Communication at Auburn University in Alabama. The author wishes to thank Avery ABernethy, Danny Bellenger, Mary Blalock, Daniel Butler, Carl Hudson and KIM Rotzoll for their critical comments and suggestions on preliminary drafts of this manuscript. that information. Advertisers selectively give and withhold information to attain their goals and may "skirt the truth," or perhaps promote misunderstanding of literally true statements, in the hopes that the facts will never be discovered [Kerton and Bodell 1987; Preston and Richards 1986, 1989]. For many products, consumers are unable to assess whether claims are true.

If consumers are unable to detect false claims, regulations could force advertisers to provide the correct information, or, at least, to stop providing the incorrect information. If advertising omits information, thereby leaving consumers with false impressions, regulations could force advertisers to provide the necessary complete information. The public policy issue is whether self-regulation provides consumers with adequate protection from the false claims they would be unable to discern on their own, or if government involvement is needed.

Many believe that self-regulation programs make government involvement unnecessary. Murray Weidenbaum, President Reagan's first chair to his Council of Economic Advisors, wrote over a decade ago that "The nearly universal adoption of and adherence to voluntary codes of business ethics should obviate the need for much of the compulsory controls over corporate governance ..." $[1979$, p. 170]. Speaking as President of the American Association of Advertising Agencies, Leonard Matthews said that network clearance and activities of the Better Business Bureaus are the best consumer protections against advertising deception [Colford 1987a].

In many other countries, self-regulation is a major force, if not the predominant factor, for advertising controls [e.g., Boddewyn 1988, 1991; Neelankavil and Stridsberg 1980; Miracle and Nevett 1987]. However, antitrust laws, plus a uniquely fragmented and highly diverse media system, impel a different set of powers and limitations for any U.S. self-regulation effort. Industry codes can suggest desired practices [e.g. Chonko, Hunt and Howell 1987], but they cannot force those practices on members [e.g., Baum 1961; Krum and Greenhill 1972; LaBarbera 1981, 1983; Maitland 1985].

Self-regulation can influence the decisions of many advertisers and government involvement is not needed when advertising is stopped by self-regulation [Oliver 1988; Steiger 
1990]. But influence alone is not the public policy issue; and self-regulation programs do not reduce the need for government involvement. There are real and pragmatic examples of the influence of advertising self-regulation, however, its effectiveness as a consumer protection device is limited. Self-regulation has restricted powers and may address different goals than consumer protection per se.

To understand the nature of self-regulation programs, researchers can take one of two slightly inter-related perspectives. Self-regulation can be researched: 1) by descriptions of regulatory "inputs," the various trade association codes or large organizations' guidelines; or 2) by reviews and analysis of regulatory "outputs," the nature of the various advertising styles or claims that different regulatory mechanisms stop or alter.

Most researchers tend to dwell on business codes or other examples, which is the first perspective listed above. While such research provides a useful starting point for study of the nature of self-regulation programs, it can be misleading. It provides more examples and descriptions of expectations than insight and assumes the codes are enforceable. Repeated mentions of these examples, in turn, imply great power and pervasive influence for the programs involved. The second perspective lends itself to understanding the differing priorities and power of government activity and various forms of self-regulation. As an inquiry into the type of claims self-regulation is capable of affecting, this perspective assesses the adequacy of self-regulation as a replacement for lessened government involvement.

\section{Perspective \#1: Codes \& Programs}

Most self-regulation studies have been tied to descriptions of business trade association codes. A few articles each provide depth analysis of activities of different single organizations [e.g., Zanot 1985; Zanot and Rotfeld 1983]. The research has been predominantly descriptive in nature and oriented toward assessment of: (1) the diffusion of codes throughout various trade organizations or ways more members might be encouraged to follow the guidelines [e.g., LaBarbera 1981, 1983]; (2) their limitations or strictness [e.g., Baum 1961; Best 1985; Garvin 1983; Levin 1967; Stern 1971]; or (3) the nature (or absence) of sanctions levied against violators [Krum and Greenhill 1972; Miracle and Nevett 1988].

By implication, presentation of examples of a trade association program or of a large organization's policies are an argument that self-regulation is an effective form of consumer protection [e.g., Boddewyn 1988; LaBarbera 1980; Neelankavil and Stridsberg 1980; Zanot 1985]. Even the pan-industry program of the Better Business Bureaus' National Advertising Division and National Advertising Review Board (NAD/NARB) is mostly presented from this perspective. Researchers describe its programs and provide examples of its successes, sometimes speculating about how it might be improved [e.g., Armstrong 1984; Armstrong and Ozanne 1983; Garvin 1983; Miracle and Nevett 1988].

Until recently, media advertising acceptance policies were discussed exclusively in terms of trade association codes or policies of major media companies such as the three major broadcast television networks [e.g., LaBarbera
1981, 1983; Linton 1967; Miracle and Nevett 1987; Zanot 1985]. This is not without historical logic. While an advertiser's trade association code might influence members' activities as the source of advertising messages, media association codes engender a secondary influence as they set guidelines for the communication channels used to convey messages to consumers.

Though the magazine and newspaper trade groups never formulated advertising codes for members [Goldstein 1986; Parsons, Rotfeld and Gray 1987], radio and television codes presented a picture of strong consumer protection. The broadcast association has dropped the direct day-today application of its codes, but a review of their previous importance helps explain how media acceptance polices can influence advertiser decisions.

\section{NAB Radio and Television Codes}

Before 1982, the National Association of Broadcaster's (NAB) Radio Code and Television Code were significant influences on broadcast advertisers' practices. Provided with offices and staff for screening commercials, NAB employees interpreted Code guidelines, reviewed commercials before submission to stations for possible broadcast, and decided which commercials would be acceptable [Heighton and Cunningham 1984]. Fewer than two-thirds of the television stations and half the radio stations followed their respective voluntary codes, but NAB codes were the basis for acceptance decisions at all three networks and many major market stations across the country [Linton 1967, 1987; Maddox and Zanot 1984]. While they could always find nonCode stations to carry NAB-rejected commercials, advertisers desiring to reach the audiences of the Code-subscribing members were forced to abide by the Code and meet its requirements. ${ }^{2}$

The Radio and Television Codes served a leadership role [Limburg 1989]; its influence was so pervasive that some researchers incorrectly attributed to government requirements common business practices based upon the codes [e.g., Ekelund and Saurman 1988, pp. 170-171]. Faced with the choice of meeting Code requirements or incurring the expense and possible public relations headaches of making two sets of commercials for Code and non-Code stations, many advertisers chose the former. For example, the NAB Code, in effect, stopped lingerie manufacturers from using live models in underwear commercials [Sloan 1987b]. Hard liquor advertisers decided that print media would be more efficient than limited use of broadcasting via the non-code stations (except advertising to Spanish language audiences, since those TV stations, until 1988, accepted hard liquor commercials [Colford 1987b; Advertising Age 1988]).

When the Justice Department sued the NAB under the anti-trust laws, and after adverse pre-trial rulings [U.S. v. National Association of Broadcasters 1982], the NAB suspended all code activities in 1982. It also dropped procedures that reviewed commercials for potentially deceptive or offensive content that were not part of the government's complaint. When asked, many stations report the nowdefunct code guidelines as the basis for current policies [Maddox and Zanot 1984; Linton 1987; Rotfeld et al. 1990]. However, station claims of adherence to the former 
Code often do not match their actual practices [Parsons and Rotfeld 1990; Rotfeld and Abernethy 1991b; Rotfeld, Abernethy, and Parsons 1990; Rotfeld et al. 1990].

\section{Effects of Codes versus Regulation}

With this lack of an industry-wide consumer protection focus by broadcasters, government eventually finds it necessary to take action. Responding to public criticisms of broadcaster's practices and their failure to serve the children audiences, Congress passed limits on child-oriented advertising. This act is currently being implemented by new Federal Communications Commission rules on the nature and number of commercials allowed during child-oriented programs [Associated Press 1991].

It has long been speculated that broadcasters' fear of new FCC regulations during the coming decade might encourage broadcasters to reinstate some type of codes [Henry 1988; McGuire 1986]. But even if the NAB Code was resurrected, it would find its adherents to be a less significant number of broadcast operations than in 1982, representing a smaller proportion of the daily audiences, and not commanding as much power as it did before. It is not because broadcast industry leaders have less desire to have a code [e.g., Le Duc 1987; Limburg 1989], but, rather, that the stations' interests, concerns and values have become increasingly varied [e.g., see Rotfeld and Parsons 1989; Parsons and Rotfeld 1990].

Therefore, examination of highly visible codes is inadequate for understanding the influence of trade association self-regulation and the overall influence of media advertising acceptance policies. In either case, the codes only indicate the goals or practices of a limited number of firms; each vehicle now follows its management's own idiosyncratic and personal basis for deciding which ads are acceptable. While examples and anecdotes of business practices provide insight into some business practices and vehicle policies [e.g., Kaplan and Houlberg 1988; Zanot 1985; Zanot and Rotfeld 1983], it would be an error to presume that what is true for some businesses is true for all media organizations [e.g., see Channels 1988a; Baum 1961; LaBarbera 1981; Rotfeld and Parsons 1989; Parsons and Rotfeld 1990; Stem 1971].

\section{Perpsective \#2: Stopping Advertising Claims}

The mere existence of guidelines is no guarantee they will be effective. This perspective of regulation and self-regulation compares the nature of claims actually stopped or otherwise influenced. Some regulatory mechanisms are not literally "gate keepers," merely discouraging certain types of advertising, or establishing procedures that halt questionable advertising after the fact. Case-by-case enforcement actions by the Federal Trade Commission (FTC), the selfregulation cases of the NAD/NARB, and many trade association codes only take action after the public has been exposed to the messages. But all advertising regulation activity imposes limitations on what, where and how different products can be advertised. Many businesses screen their ad- vertising to reduce the risks of regulatory problems [e.g., Zanot 1985; Zanot and Rotfeld 1983].

Different types of regulatory mechanisms address and influence different advertising claims or styles and regulation by peers is more "painless" than government action [LaBarbera 1980; Stern 1971]. But there are limits to the types of advertising that self-regulation is willing to address, and some firms will refuse to follow trade association guidelines or participate in self-regulation activities [Garvin 1983; LaBarbera 1983; Maitland 1985]. This perspective compares and contrasts the types of advertising influenced by different forms of regulation by looking at the power and priorities of different mechanisms.

\section{The Power of Trade Association Codes}

The trade associations recognize that any attempts at coercive enforcement risk violation of the U.S. anti-trust laws, and, therefore, some of these organizations totally abstain from any enforcement of their codes [Baum 1961; Best 1985; LaBarbera 1981, 1983]. If a trade association attempts to mandate stricter requirements than the relevant regulatory agencies, or go into areas the law cannot address, member cooperation will be low, and total impact might be insignificant [e.g., Garvin 1983; Maitland 1985; Wyckham 1987].

Because of the anti-trust laws, trade associations' only self-regulation enforcement powers are limited to member cooperation, often engendered by current or threatened government action [e.g., LaBarbera 1981; Levin 1967; Maitland 1985; Zanot 1979]. An organization can expel an uncooperative member, though the literature has never recognized this as a meaningful sanction since membership is itself voluntary. A trade association can publicize a case involving a recalcitrant member, though this might discourage future cooperation from other members who would fear any corporate data provided to the association later being used against them [e.g., Miracle and Nevett 1988]. The association also can tum self-regulation files over to relevant government organizations, but this, too, can have a negative impact on future member cooperation and is dependent on the nature of the government regulatory concerns.

Therefore, trade associations can only take action against fewer types or styles of advertising claims than regulations promulgated or threatened by the relevant government regulatory body. In Figure 1 (as in the similarly-structured Figure 2), the arrows represent questionable claims, products or advertising styles that advertisers might otherwise send toward consumers. The boxes represent the types of claims or advertising styles influenced or stopped by various regulatory mechanisms. Dependent on member fear of government action for authority, industry codes of advertising selfregulation stop fewer types of "questionable" advertising claims than would be stopped-or might be threatened to be stopped-by the relevant government body that regulates practices for the businesses in that trade association (Figure 1).

Trade association guidelines ultimately are enforced against fewer types of advertising claims than the government can or would. It cannot enforce actions in areas that member firms know would never be the basis for govern- 
Figure 1. Types of Claims Influenced by Trade Association Codes \& Government Regulation

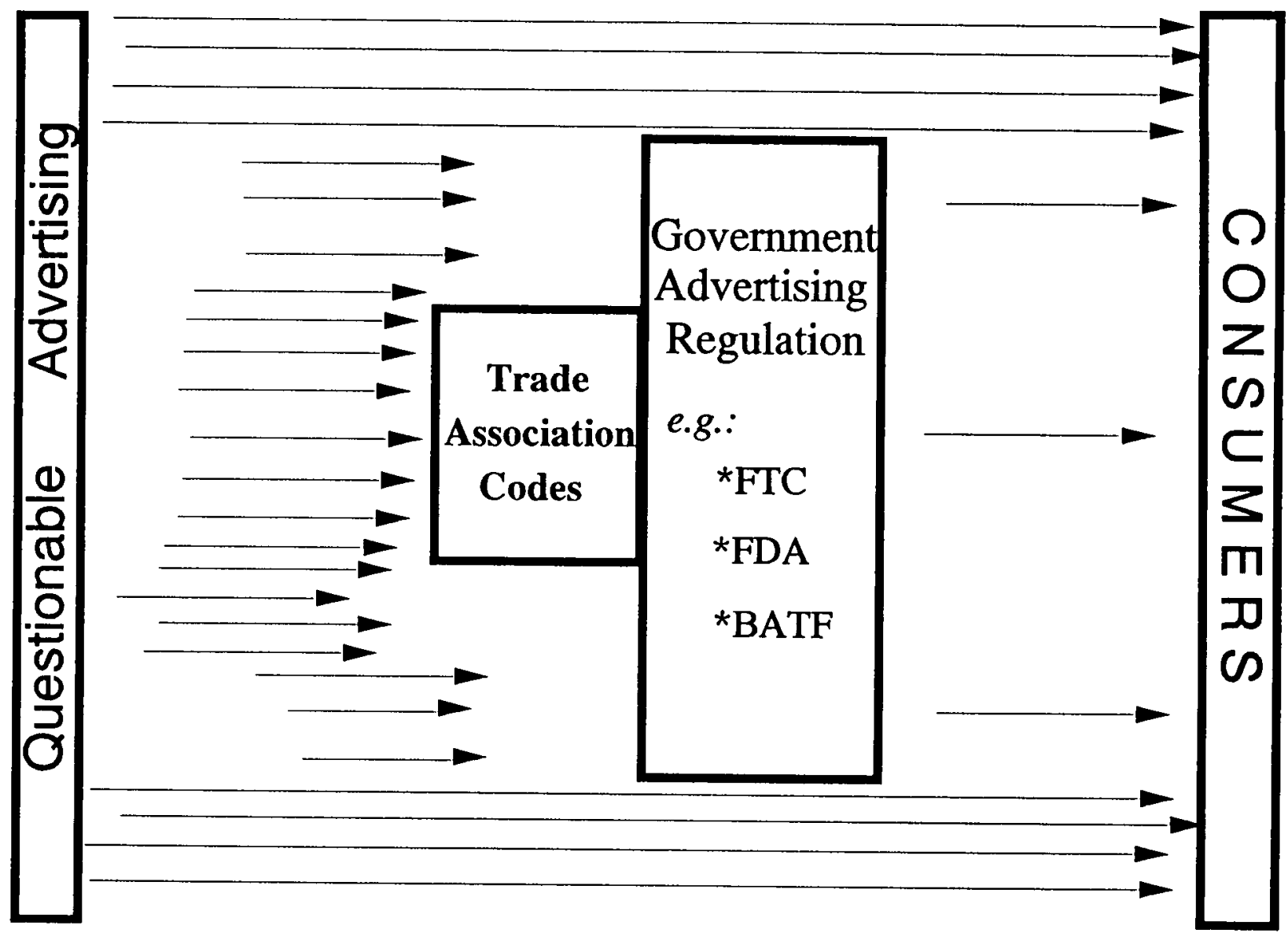

ment involvement. It cannot force a member firm to cooperate with the procedure. A trade association's activities might occasionally seem to go beyond actual government requirements, but only in reaction to fears of new government regulations under consideration. Codes also may attempt to discourage member activities that provoke public criticisms that could engender greater regulation.

The NAD/NARB was initially established when the FTC became more active in advertising regulation in the early 1970s [Armstrong and Ozanne 1983; Garvin 1983; Zanot 1979]. The Children's Advertising Review Unit was an industry reaction to public criticisms and government hearings about potential restrictions on advertising to this vulnerable target audience [Armstrong 1984]. The mere existence of Federal Communications Commission and FTC hearings on child-oriented advertising during the 1970s engendered various self-conscious self-regulatory efforts by advertisers, with activity dropping off as the hearings ended without producing any new regulations. The Bureau of Alcohol, Tobacco and Firearms (BATF) regulated liquor advertising to address public concerns over perceived relations between advertising and alcohol abuse. In response, the trade organization code limited advertising forms and media styles for members to show that greater government regulatory activ- ity would be unnecessary [Distilled Spirits Council of United States 1985].

Figure 1 illustrates that trade association codes cannot "replace" government programs as a focus for attaining public policy goals. While such programs do influence some advertising practices for the consumer's benefit [e.g., Armstrong 1984; Boddewyn 1989, 1991; Garvin 1983], as a trade group's relevant government regulations decrease, so would the power and influence of its self-regulation efforts [Maitland 1985]. Trade codes might sometimes be born of the social conscience of some firms, but self-regulation in the United States tends to be a form of industrial selfdefense from government regulation [e.g., Baudot 1989; Neelankavil and Stridsberg 1980]. Absent any government interest, the self-regulatory body is, in practical terms, powerless [Boddewyn 1988, pp. 308-310; Garvin 1983; Maitland 1985].

\section{Individual Vehicles' Standards for Acceptable Advertising}

Trade association codes address members' advertising, regulating them as the source of advertising messages. The adoption of media standards for acceptable advertising forms a different type of influence, setting limitations on the communication channels the advertisers must use to con- 
vey their messages to consumers. To reach a media vehicle's audience, the advertiser must meet that vehicle's requirements.

Regardless of the directives (or absence) of any selfregulation code, no media vehicle must accept any commercial advertising it does not wish to carry. But media advertising acceptance policies are not concerned with the nature of advertising practice per se. They tend to view advertising material as a portion of the vehicles' total content. Advertising regulation is an effect of clearance procedures, not a goal.

Advertising truth and consumer protection might be the basis for advertising acceptance decisions by some media vehicle managers for a variety of personal reasons [Rotfeld and Parsons 1989]. Media organizations might operate with clearance officers who are as staunchly consumer protection oriented as those in any government office, but research data suggest that such activities are far from typical. More commonly, the primary "consumer protection" activity seems to be an interest in avoiding or responding to consumer complaints, driven by concerns for audience loyalty, with infrequent regulation of false claims [Hayes and Rotfeld 1989; Le Duc 1987; Parsons and Rotfeld 1990;
Rotfeld and Abernethy 1991b; Rotfeld et al. 1990; Smythe 1989].

Figure 2 illustrates that, while media acceptance restrictions might stop questionable advertising that also would be halted by government consumer protection programs, such overlap is not a direct function of the vehicles' policies. ${ }^{3} \mathrm{~A}$ media vehicle owner or manager may choose to reject only those claims whose false nature is obvious, never asking advertisers for substantiation of claims. Conversely, managers may instead demand that advertisers meet requirements that could never be legally required by government regulations, refusing certain subject matter or presentation styles [LaBarbera 1983; Rotfeld and Parsons 1989]. They can hold advertisers to even higher standards of claim substantiation than required by government [Code of Federal Regulation 1979; Henry 1988; Sewell and Jennerjahn 1982]. But overall, potential audience deception is not a common vehicle concern in deciding which ads are acceptable for publication or broadcast.

Pasternack and Utt's [1988] responses from 75 newspapers indicated little interest in consumer protection, with most concerns directed toward specific products that readers might find objectionable. A review of policies at 164 magazines found that the most common concern was a gen-

Figure 2. Types of Claims \& Styles Influenced by the Clearance Process and Government Regulation

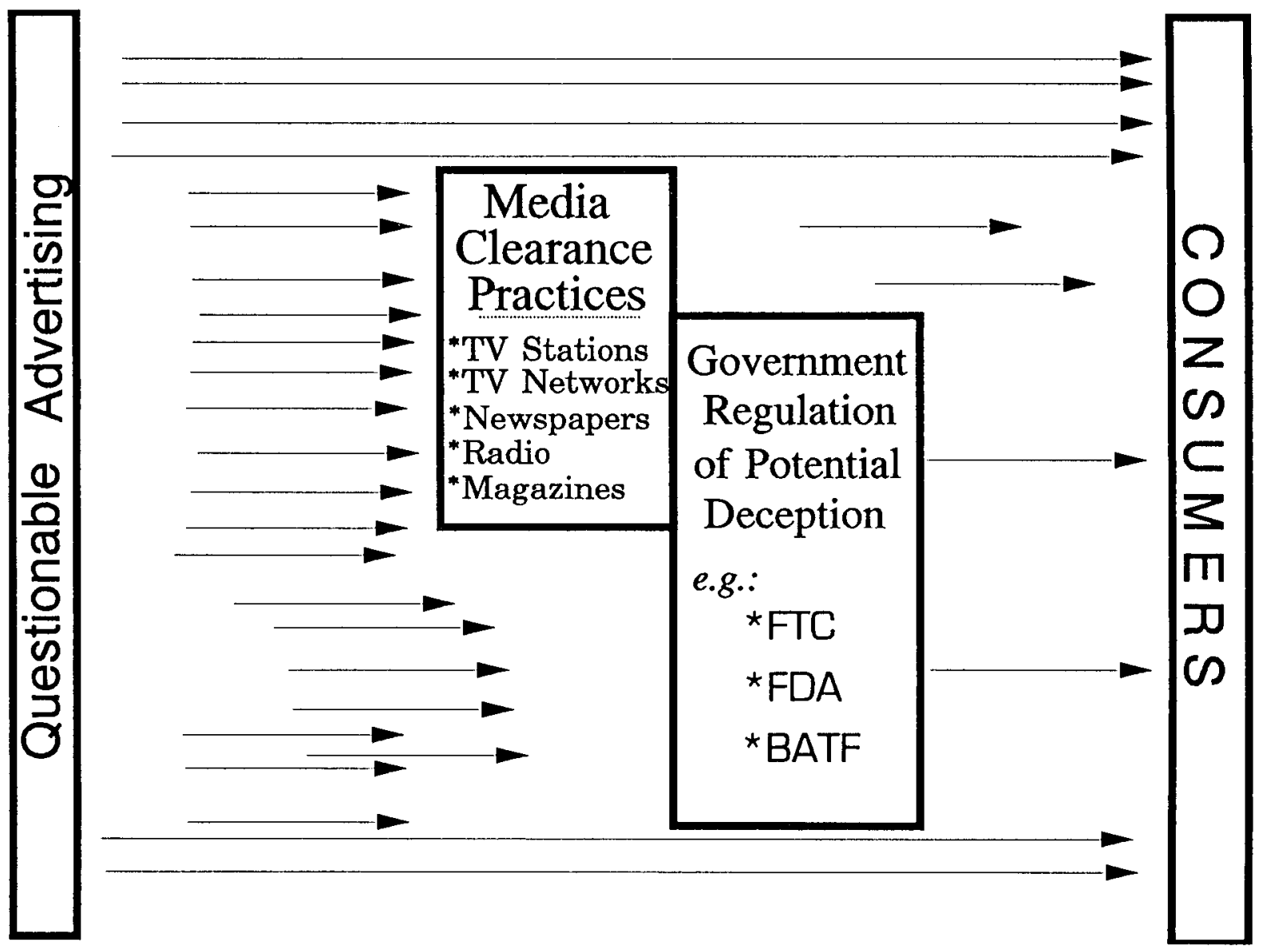


eral concern for "good taste," which often meant nothing more than degrees of sexual explicitness [Rotfeld and Parsons 1989]. Many magazines are concerned that the ads are an appropriate fit with the editorial material [Rotfeld and Parsons 1989].

In broadcasting, Capital Cities/ABC, CBS and NBC all follow written codes adopted when the NAB dropped its clearance procedures [Maddox and Zanot 1984; Linton 1987]. While the three organizations often do not agree with each other on actual acceptance decisions for individual commercials [see Dunn et al. 1990; Heighton and Cunningham 1984; Sewell and Jennerjahn 1982; Walley 1990], they sometimes influence advertising practices in a manner akin to that previously done by the NAB [Davis 1987].

For example, live models wearing underwear came to television when the networks decided to allow such displays [Sloan 1987b]. The networks' style and "taste" concerns for various cologne and perfume commercials set a standard that can direct major changes in presentation [Freeman 1987; Sloan 1987a]. Contemporary practices also illustrate how some vehicles' acceptance decisions might run counter to other public policy goals, such as network decisions that have been seen as a hindrance to AIDS and "safe sex" public information campaigns when they rejected condom advertising and related Public Service Announcements [Colford 1987c; Christopher 1986; Garneau 1985; Rotfeld and Abernethy 1991a; Winters 1987].

Similar to some print vehicles, the three major broadcast networks employ staff members for the sole job of screening advertising, and their policies and have been the focus of many research studies. While the networks influence many advertisers' decisions [e.g., Colford 1987c; Davis 1987; Freeman 1987; Henry 1988; Zanot and Rotfeld 1983], they cut back on staff and activity in this area during 1988 for a variety of reasons [Channels 1988b; Gordon 1988]. As network audience shares decline and the number of additional cable and independent options increases [Channels 1988a], there are many other outlets for commercials that never undergo review by the networks [Hayes and Rotfeld 1989; Parsons and Rotfeld 1990; Rotfeld and Abernethy 1991b; Steiger 1990; Walley 1990].

There is a wide variation in the willingness of individual television stations to ask advertisers to substantiate claims or reject commercial submissions; many stations accept almost anything [Rotfeld, Abernethy, and Parsons 1990]. Survey responses from radio station managers suggest that the technical details of the commercials' production quality are the major priority [Rotfeld and Abernethy 1991b]. CableTV networks look to a mix of these concerns: The fit between the advertising and programs that might run on the network, followed by the technical and aesthetic production quality of the commercial, and then, whether the style of presentation might offend the viewing audience [Hayes and Rotfeld 1989].

Some policies requiring the rejection of controversial products such as alcohol, cigarettes or casino gambling might be mandated by government [Pasternack and Utt 1988], and broadcaster advertising acceptance policies may partially include a response to threatened government actions. However, broadcasters attend to different concerns than the consumer protection priorities of government advertising deception regulations. The broadcasters' focus, similar to that of the now-defunct NAB-Codes, is FCC regulations, not the consumer protection concerns of the FTC. The Federal Communications Commission lacks rules or programs to check commercials to make certain their claims are true. It issues licenses to television and radio station owners to operate on assigned frequencies and to serve the "public interest, convenience and necessity." Practices that might threaten license renewals were the core of the NAB Codes, with a focus on advertising that would engender audience complaints, not the broadcast of commercials later determined by the FTC to be deceptive. Complaints could be presented to the FCC as evidence that the license holder was failing to serve community interests [Le Duc 1987].

\section{Variation in Vehicles' Consumer Protection}

Clearly, vehicles with large or precisely targeted audiences can dictate terms more readily to advertisers wishing to reach those audiences. Operating on an assumption that the "largest" media operations are the strictest, some argue that restrictions imposed by media advertising acceptance policies are an adequate consumer protection force. In other words, since the three major commercial networks review and restrict many ads, it is presumed that most television commercials are effectively controlled.

Case studies of advertising acceptance policies and practices can easily find examples of media managers that forgo revenue to meet audience protection goals [e.g., Kaplan and Houlberg 1988; Colford 1987a; Sewell and Jennerjahn 1982; Walley 1990]. On the other hand, consumer advocates see major gaps in the system, noting that the media are not doing enough [e.g., Marketing News 1985; Hamm 1988] and that many audiences are unprotected [e.g., Baum 1961; Best 1985; Goldstein 1986; Hayes and Rotfeld 1989; Rotfeld and Parsons 1989; Pasternack and Utt 1988]. Many FTC cases are against commercials running on the three commercial broadcast networks [Steiger 1990]. And other advertisers can avoid strict vehicles altogether [Hayes and Rotfeld 1989; Parsons and Rotfeld 1990; Rotfeld and Parsons 1989].

It is difficult to discern what prompts concern for consumer protection or which media organizations are strictest. The conventional wisdom is that a vehicle's willingness to reject questionable advertising claims depends upon its market position. In other words, small publishers or broadcasters are expected to be willing to accept almost anything merely to stay solvent. As they become larger or more economically stable, they might acquire the desire to let management's ethical concerns dictate involvement in "public service," resulting in rejection of more advertiser submissions.

In print media, the publisher usually has primary responsibility for advertising decisions. Since a publisher's job performance is judged by revenue, maximization of advertising income is inextricably linked to advertising policies and decisions. Yet, it is difficult to discern just what role finan- 
cial concerns play for which publications, since no significant correlations have been found to exist between acceptance standards and circulation [Parsons, Rotfeld, and Gray 1987; Rotfeld and Parsons 1989; Pasternack and Utt 1988].

Published data have yet to support any size-based relationship, and if any such relationship were found, it would likely be very weak. Some magazines and newspapers report a policy of accepting everything based on a First Amendment rationale [Goldstein 1986; Parsons, Rotfeld, and Gray 1987; Rotfeld and Parsons 1989]. Managers at large-size vehicles might have been trained and acculturated when the operation was smaller and less secure. In addition, some small-circulation vehicles might be able to exert great influence because of advertiser demand for their highly-specialized audiences, while some larger vehicles have audiences readily reached by several alternatives [e.g., Walley 1990].

Attempts to apply various surrogate measures of station size, location or market power also didn't find any correlations with television or radio station standards [Rotfeld et al. 1990; Rotfeld and Abernethy 1991b; Rotfeld, Abernethy, and Parsons 1990]. Network affiliation or broadcast frequency was once seen as a valid indicator of station profitability, but new stations and fledgling networks (e.g., Fox) limit the validity of such assumptions [Channels 1988a], and they, too, have not shown any significant relationship with station practices [Rotfeld, Abernethy, and Parsons 1990].

Clearance guidelines cut off many product ads, presentation styles and types of claims from many consumers. But many advertisers' claims are never subjected to restrictions of the strict vehicles and the typical consumer lacks any way of knowing which vehicles provide this protection.

The influence and power of advertising acceptance policies is tied to a question of point of view. To an advertiser whose primary targets are audiences of restrictive vehicles, media advertising acceptance policies must form a significant aspect of advertising planning [Rotfeld et al. 1990; Rotfeld and Parsons 1989]. Similarly, advertisers who wish to reach well protected audiences only part of the time might see these clearance requirements as an important part of the regulatory landscape. However, a consumer advocate would be interested in how thoroughly the clearance process substitutes for laws and regulations and, accordingly, focuses attention on the quantity of deceptive advertising claims that are not stopped. Absent government involvement, there are many gaps in consumer protection.

\section{Conclusions and Implications}

Repeated descriptions of highly visible programs have engendered popular faith in the power of self-regulation. But these descriptions only illustrate what the most self-conscious firms do. Similarly, media standards for acceptable advertising deliver less consumer protection than many presume. Some media vehicles impose strong standards on the types of advertising content they will accept for broadcast or publication and are examples of how these policies can influence advertising practice. But it would be a gross error to presume that such standards are typical. More directly, the primary goal of advertising acceptance policies are in terms of overall vehicle content, not consumer protection.

There are many valid reasons for deregulation and many examples of government regulations that are contrary to best interests of consumers [see Ekelund and Saurman 1988]. However, it is not valid to assert that self-regulation alone makes government programs "unnecessary." If greater self-regulation activity is desired, increased government regulation would be needed to serve as a motivation for that self-regulation.

Of course, some firms' self-regulation activity might be motivated by a concern for public welfare. But for most firms, it is more often best described as "enlightened selfinterest." Given that government is the motivating force for business cooperation with self-regulation, as government enforcement activity is cut back, so is the power of selfregulation. If government agencies have not paid adequate attention to advertising deception issues [e.g., American Bar Association 1989], the incentive for self-regulation is proportionately weakened.

This is not to deny the potential role and influence of selfregulation in consumer protection. No single regulatory program can eliminate all deceptive advertising. In a sense, self-regulation does "augment" government programs. Many trade associations and the Better Business Bureau's National Advertising Division are doing a good job of protecting consumers insofar as they are able. Self-regulation might be faster and more efficient than government for firms who cooperate. But not all businesses would want to participate.

It must be remembered that government programs set the framework for all desirable self-regulation practices. Without the threat of government action, only the most altruistic of firms would ever pay heed to self-regulation directives. Strong and efficient government regulation is a necessary prerequisite for effective advertising self-regulation, therefore, advocates for stronger self-regulation must also desire vigilant government activity.

\section{Notes}

1. The intrusive broadcast media face regulatory restrictions on offensive content, but these restrictions are imposed on broadcasters, not advertisers [Le Duc 1987]. Similarly, restrictions imposed by any obscenity laws regulate the media.

2. For a practitioner's description and criticisms of this process, calling it one person's "hang-ups," see Della Femina's discussion of what he labeled "Censorship" [1970, ch. 10].

3. While similar in structure and presentation style, Figures 1 and 2 are independent qualitative illustrations of the nature of claims influenced by various regulatory mechanisms. They should not combined or taken together to view the total number of claims influenced by all forms of self-regulation.

\section{References}

Advertising Age (1988), "Hispanic Tv's New Maturity," editorial, 59 (September 19), 16.

American Bar Association (1989), Report of the American Bar Association Section of Antitrust Law Special Committee to Study the Role of the Federal Trade Commission. 
Armstrong, Gary M. (1984), “An Evaluation of the Children's Advertising Review Unit," Journal of Public Policy \& Marketing, $3,38-55$.

and Julie L. Ozanne (1983), "An Evaluation of the NAD/ NARB Purpose and Performance," Journal of Advertising, 12 (3), 15-26, 52

Associated Press (1991), "FCC Tightens Rules on When Kids' TV Show is Really a Commercial," Marketing News, 25 (May 13), 1,9

Baudot, Barbera Sundberg (1989), International Advertising Handbook: A User's Guide to Rules and Regulations. Lexington, Mass.: D.C. Heath \& Company.

Baum, Daniel Jay (1961), "Self Regulation and Antitrust: Suppression of Deceptive Advertising by the Publishing Media," Syracuse Law Review, 12 (Spring), 289-304.

Best, Arthur (1985), "Controlling False Advertising: A Comparative Study of Public Regulation, Industry Self-Policing and Private Litigation," Georgia Law Review, 20 (Fall), 1-72.

Boddewyn, Jean J. (1988), Advertising Self-Regulation and Outside Participation: A Multinational Comparison. New York: Quorum Books.

(1989), "Advertising Self-Regulation: True Purpose and Performance," Journal of Advertising, 18 (2), 19-27.

(1991), "Controlling Sex and Decency in Advertising Around the World," Journal of Advertising, 20, in press.

Channels: The Business of Communications (1988a), "Local Television Under Fire," 1989 Field Guide to the Electronic Media, 8 (December), 10-22.

(1988b), “Networks to Censors: Take a Walk," 8 (October), 12-13.

Christopher, Maurine (1986), "Nets Stand Fast on Birth Control Ads," Advertising Age, 57 (November 10), 36

Chonko, Lawrence B., Shelby D. Hunt, and Roy D. Howell (1987), "Ethics and the American Advertising Federation Principles," International Journal of Advertising, 6 (October), 265274.

Code of Federal Regulation (1979), "In Regard to Comparison Advertising, 'Substantiation',' 16 (sect. 14.15, subsect. 2), 145.

Colford, Steven W. (1987a), "Four A's Pushes Nets on Screening Ads,' Advertising Age, 58 (April 20), 36.

(1987b), "Hispanic TV Stations Under Fire," Advertising Age, 58 (October 12), 12.

$(1987 \mathrm{c})$, "Nets Take Flak on Condom Ads," Advertising Age, 58 (February 16), 79.

Davis, L. J. (1987), "Looser, Yes, But Still the Deans of Discipline," Channels: The Business of Communication, 7 (July/ August), 32-38.

Della Femina, Jerry (1970), From Those Wonder Folks Who Gave You Pearl Harbor: Front-line Dispatches from the Advertising War, Charles Sopkin, ed. New York: Simon and Schuster.

Distilled Spirits Council of United States (1985), “A Spirit of Responsibility."

Dunn, S. Watson, Arnold M. Barban, Dean Krugman, and Leonard N. Reid (1990), Advertising: It's Role in Modern Marketing, 7th edition. Hinsdale, Ill.: The Dryden Press.

Ekelund, Robert B., Jr, and David S. Saurman (1988), Advertising and the Market Process: A Modern Economic View. San Francisco: Pacific Research Institute for Public Policy.
Freeman, Laurie (1987), “Jovan's Torrid Spot Steams Up Networks," Advertising Age, 58 (October 12), 3, 96.

Garneau, George (1985), “TV Networks Refuse to Air Public Service Campaign," Editor \& Publisher, 118 (August 10), 18.

Garvin, David A. (1983), "Can Industry Self-Regulation Work?" California Management Review, 25 (Summer), 37-52.

Goldstein, Tom (1986), A Two-Faced Press. New York: Priority Press Publications.

Gordon, Richard L. (1988), "Networks Hit for Ad Clearance Cuts," Advertising Age, 59 (September 12), 6.

Hamm, S.W. (1988), "The Media Should Do More to Monitor False and Deceptive Advertisements," At Home With Consumers: The Direct Selling Education Foundation Newsletter, 9 (1), 4.

Hayes, Rader and Herbert J. Rotfeld (1989), "Infomercials \& Cable Network Programming," Advancing the Consumer Interest, 1 (2), 17-22.

Heighton, Elizabeth J. and Don R. Cunningham (1984), Advertising in the Broadcast and Cable Media, 2nd edition. Belmont, Calif.: Wadsworth Publishing Company.

Henry, William A. III (1988), "Network to Censors: Take a Walk," Channels: The Business of Communication, 8 (October), 12-13.

Kaplan, Herb and Rick Houlberg (1988), "Broadcast Condom Advertising, the Public Interest, and Deregulation: A Case Study," paper presented at International Communications Association conference, New Orleans, May 30.

Kerton, Robert R. and Richard W. Bodell, (1987), "The Economic Imperative to Conceal: Why Sellers Hide Information About Defects," Proceedings of 33rd Annual Conference of the American Council on Consumer Interests, V. Hampton, ed. Columbia, Mo.: American Council on Consumer Interests, pp. 8793.

Krum, James R. and Richard H. Greenhill (1972), "The Extent of Industry Self-Regulation Through Trade Association Codes of Ethics," The Anti-Trust Bulletin, 17 (Summer), 379-92.

LaBarbera, Priscilla A. (1980), "Analyzing and Advancing the State of the Art of Advertising Self-Regulation," Journal of Advertising, 9 (4), 27-38.

(1981), "The Antitrust Shadow over Advertising SelfRegulation," Current Issues and Research in Advertising, 4, 57 70

(1983), "The Diffusion of Trade Association Advertising Self-Regulation," Journal of Marketing, 47 (Winter), 58-67.

Le Duc, Don R. (1987), Beyond Broadcasting: Patterns in Policy and Law. White Plains, N.Y.: Longman Inc.

Levin, Harvey J. (1967), "The Limits of Self-Regulation," Columbia Law Review, 67 (April), 603-644.

Limburg, Val E. (1989), "The Decline of Broadcast Ethics: U.S. v. NAB," Journal of Mass Media Ethics, 4 (Fall), 214-231.

Linton, Bruce A. (1967), Self-Regulation in Broadcasting. Washington, D.C.: National Association of Broadcasters.

(1987), "Self-Regulation in Broadcasting Revisited," Journalism Quarterly, 64 (Summer-Autumn), 483-490.

Maddox, Lynda M. and Eric J. Zanot (1984), "Suspension of the NAB Code and Its Effect on Regulation of Advertising," Journalism Quarterly, 61 (Spring), 125-130, 156. 
Maitland, Ian (1985), "The Limits of Business Self-Regulation," California Management Review, 27 (Spring), 132-147.

Marketing News (1985), "Media Must Screen Out Fraudulent Advertising," 19 (December 6), 11.

McGuire, Bernadette (1986), "The National Association of Broadcasters' View of Alcohol Advertising,' in Proceedings of 1986 Conference of the American Academy of Advertising, E.F. Larkin, ed. Norman, Okla.: University of Oklahoma School of Journalism, pp. NR119-NR121.

Miracle, Gordon E. and Terence Nevett (1987), Voluntary Regulation of Advertising: A Comparative Analysis of the United Kingdom and the United States. Lexington, Mass.: D.C. Heath \& Company.

and (1988), "Improving NAD/NARB Self-Regulation of Advertising,' Journal of Public Policy \& Marketing, 7, 114126.

Neelankavil, James P. and Albert B. Stridsberg (1980), Advertising Self-Regulation: A Global Perspective. New York: Hastings House.

Oliver, Daniel (1988), "Who Should Regulate Advertising and Why?" International Journal of Advertising, 7 (1), 1-9.

Parsons, Patrick R. and Herbert J. Rotfeld (1990), "Infomercials and Television Station Clearance Practices;" Journal of Public Policy \& Marketing, 9, 62-72.

and Todd Gray (1987), "Magazine Publisher and Advertising Manager Standards for Acceptable Advertising," Current Issues and Research in Advertising, 10, 199-211.

Pasternack, Steve and Sandra H. Utt (1988), “Newspapers' Policies on Rejection of Ads for Products and Services," Journalism Quarterly, 65 (Fall), 695-701.

Preston, Ivan L. and Jef I. Richards (1986), "The Relationship of Miscomprehension to Deceptiveness in FTC Cases," in Advances in Consumer Research, Vol. 12, Richard J. Lutz, ed. Provo, Utah: Association for Consumer Research, 138-142.

and (1989), "The Costs of Prohibiting Deceptive Advertising-Are They as Substantial as Economic Analysis Implies?" in Advances in Consumer Research, Vol. 16, Provo, Utah: Association for Consumer Research, 209-214.

Rotfeld, Herbert J. and Avery M. Abernethy (1991a), "Radio Station Acceptance of AIDS-Related Advertising Messages," Journal of Health Care Marketing, 11 (June), 33-40.

and ___ (1991b), "Radio Station Standards for Acceptable Advertising," Journal of Business Research, in press. and Patrick R. Parsons (1990), "Self-Regulation and Television Advertising,' Journal of Advertising, 19 (4), 18-26. and Patrick R. Parsons (1989), "Self-Regulation and Magazine Advertising," Journal of Advertising, 18 (4), 33-40.

Avery M. Abernethy, and John V. Pavlik (1990), "Television Station Standards for Acceptable Advertising," Journal of Consumer Affairs, 24 (Winter), 392-410.

Sewell, Michael and Mary Lou Jennerjahn (1982), "Advertising Gatekeeping: Clearance of Network Television Commercials," in Studies in Journalism and Mass Communications, review from the Southwest Education Council for Journalism/Mass Communications conference, (October 3-4), pp. 20-26.

Sloan, Pat (1987a), “Alfin Skin Line Ignites Controversy," Advertising Age, 58 (February 23), 32.

(1987b), "Burning Up Over Bras," Advertising Age, 58 (April 27), 75 .

Smythe, Dallas W. (1989), "Television Deregulation and the Public: A Critique," Journal of Communications, (Autumn), 133137.

Steiger, Janet D. (1990), Remarks by the Chair of the Federal Trade Commission before the American Advertising Federation Spring Government Affairs Conference in Washington, D.C. (March 6).

Stern, Louis L. (1971), "Consumer Self-Protection Via SelfRegulation," Journal of Marketing, 35 (July), 47-53.

U.S. versus National Association of Broadcasters (1982), 536 F. Supp. 149, D.C. Dist.

Walley, Wayne (1990), "Network Ad Rejections: At What Cost?"' Advertising Age, 61 (April 4), 22.

Weidenbaum, Murray L. (1979), The Future of Business Regulation. New York: AMACOM.

Winters, Patricia (1987), "'TV Stations Embrace Condom Spots," Advertising Age, 58 (February 2), 4.

Wyckham, Robert G. (1987), “Self-Regulation of Sex-Role Stereotyping in Advertising: The Canadian Experience," Journal of Public Policy \& Marketing, 6, 76-92.

Zanot, Eric J. (1979), "The National Advertising Review Board: 1971-1976,' Journalism Monographs, 59 (February).

(1985), "Unseen But Effective Advertising Regulation: The Clearance Process," Journal of Advertising, 14 (4), 44-51, 59, 68.

and Herbert J. Rotfeld (1983), "A Comparison and Contrast of Clearance Procedures in Four Advertising Agencies," Proceedings of the 1983 Convention of the American Academy of Advertising, D.W. Jugenheimer, ed. Lawrence, Kan.: American Academy of Advertising, pp. 47-51. 